\title{
Brewer's spent grain: a valuable feedstock for industrial applications
}

\section{Solange I Mussatto*}

\begin{abstract}
Brewer's spent grain (BSG) is the most abundant by-product generated from the beer-brewing process, representing approximately $\mathbf{8 5 \%}$ of the total by-products obtained. This material is basically constituted by the barley grain husks obtained as solid residue after the wort production. Since BSG is rich in sugars and proteins, the main and quickest alternative for elimination of this industrial by-product has been as animal feed. However, BSG is a raw material of interest for application in different areas because of its low cost, large availability throughout the year and valuable chemical composition. In the last decade, many efforts have been directed towards the reuse of BSG, taking into account the incentive that has been given to recycle the wastes and by-products generated by industrial activities. Currently, many interesting and advantageous methods for application of BSG in foods, in energy production and in chemical and biotechnological processes have been reported. The present study presents and discusses the most recent perspectives for BSG application in such areas.
\end{abstract}

(c) 2013 Society of Chemical Industry

Keywords: brewer's spent grain (BSG); chemical composition; ethanol; adsorbent; fermentation; biotechnological processes

\section{INTRODUCTION}

Briefly, the beer-brewing process starts with the production of the wort, a sugar-rich solution that will be used in the subsequent fermentation stage to produce ethanol. For the wort elaboration, the milled barley malt is mixed with water in a mash tun where the temperature is slowly increased from 37 to $78{ }^{\circ} \mathrm{C}$ in order to convert the malt starch into fermentable (mainly maltose and maltotriose) and non-fermentable (dextrins) sugars. Proteins from the barley malt are also partially degraded during this stage into polypeptides and amino acids. At the end of this process, the insoluble undegraded part of the barley malt grain, also known as brewer's spent grain (BSG), is obtained in mixture with the wort. The wort is filtered through the BSG bed formed at the bottom of the mash tun and is transferred to the fermentation tank, while BSG is obtained as a by-product of this process. More details on the beer-brewing process and the by-products generated during this process can be found in previously published studies. ${ }^{1,2}$

BSG is constituted by the husks that covered the original barley malt grain in mixture with part of the pericarp and seed coat layers that are obtained as residual solid material after the wort elaboration step. In some cases, according to the kind of beer that will be produced, other cereals such as corn (maize), rice, wheat, oats, rye or sorghum can be used in mixture with the barley malt for the wort elaboration. In such cases, the insoluble part of these grains after the mashing process is separated with BSG as a unique fraction. Therefore BSG can be derived from barley malt only or from a mixture of barley malt with adjuncts (other cereal grains).

The worldwide annual production of BSG has been estimated as approximately $38.6 \times 10^{6}$ t. This is a significant amount considering that BSG is obtained only from the barley husks and that not all the produced barley is used for the production of beer. Compared with the total amount of by-products generated from the most important agricultural crops, ${ }^{3-6}$ the amount of BSG produced annually is much lower (Table 1). However, the values reported for the other by-products correspond to the sum of husks, straws, leaves and stems derived from these crops, while BSG is derived only from the barley husks. Owing to the significant amount in which it is produced annually, efforts must be made to valorize this agro-industrial by-product derived from breweries.

\section{BSG COMPOSITION}

BSG is mainly composed of the barley malt grain husks in mixture with part of the pericarp and seed coat layers of these grains. Although it is well known that BSG is rich in sugars, proteins and minerals, the chemical composition of this material may suffer significant variations due to a variety of factors, which include the variety of the barley used in the process as well as its harvest time and the conditions under which it was cultivated, the conditions used for malting and mashing and the amount and type of the adjuncts added in mixture with the barley malt for the wort elaboration. Table 2 summarizes the chemical composition of BSG reported in different studies, which used barley malt produced in different countries, including Brazil, ${ }^{7}$ Japan, ${ }^{8}$ Portugal ${ }^{9-11}$ and Ireland. ${ }^{12}$ This table clearly shows variations in the chemical composition of this raw material as a consequence of the above-mentioned factors. For example, Mussatto and Roberto ${ }^{7}$ and Waters et al. ${ }^{12}$ used BSG derived from a brewing process without addition of adjuncts (i.e. using $100 \%$ barley malt), but the former used Brazilian barley malt while

\footnotetext{
* Correspondence to: Solange I Mussatto, Institute for Biotechnology and Bioengineering (IBB), Centre of Biological Engineering, University of Minho, Campus Gualtar, 4710-057, Braga, Portugal.E-mail: solange@deb.uminho.pt; solangemussatto@hotmail.com

Institute for Biotechnology and Bioengineering (IBB), Centre of Biological Engineering, University of Minho, Campus Gualtar, 4710-057 Braga, Portugal
} 
Table 1. Annual worldwide production of brewer's spent grain (BSG), some of the most important agricultural crops and their by-products in 2011

Total annual
Item production $\left(10^{6} \mathrm{t}\right) \quad$ By-products $\left(10^{6} \mathrm{t}\right)$

Agricultural crops

\begin{tabular}{|c|c|c|}
\hline Wheat & $694.02^{\mathrm{a}}$ & $763.42^{\mathrm{b}}$ \\
\hline Rice & $465.40^{\mathrm{a}}$ & $698.10^{\mathrm{b}}$ \\
\hline Corn & $864.96^{\mathrm{a}}$ & $1729.92^{\mathrm{b}}$ \\
\hline Soybean & $245.07^{\mathrm{a}}$ & $416.62^{\mathrm{b}}$ \\
\hline Cotton & $126.92^{\mathrm{a}}$ & $107.13^{b}$ \\
\hline Barley & $124.07^{\mathrm{c}}$ & $144.88^{\mathrm{d}}$ \\
\hline \multicolumn{3}{|c|}{ Agro-industrial residue } \\
\hline BSG & & $38.60^{\mathrm{e}}$ \\
\hline \multicolumn{3}{|l|}{ a USDA. ${ }^{3}$} \\
\hline \multicolumn{3}{|c|}{ b Zhang et al. ${ }^{4}$} \\
\hline \multicolumn{3}{|c|}{${ }^{C}$ De Mori and Minella. ${ }^{5}$} \\
\hline \multicolumn{3}{|c|}{${ }^{\mathrm{d}}$ Estimated considering a residue/crop ratio of $1.2{ }^{6}$} \\
\hline $\begin{array}{l}\text { e Estimate } \\
(1930 \times 1\end{array}$ & $\begin{array}{l}\text { the ann } \\
\text { yeneratior }\end{array}$ & $\begin{array}{l}\text { beer in } 2011 \\
\text { eer produced. }\end{array}$ \\
\hline
\end{tabular}

the latter used barley malt from Ireland. Differences can also be observed when comparing the results of these authors with those reported by Meneses et al., ${ }^{11}$ who used BSG derived from a process using barley malt with adjuncts. Carvalheiro et al. ${ }^{9}$ and Meneses et al. ${ }^{11}$ used BSG derived from barley malt with adjuncts, obtained from two different Portuguese breweries. The variations observed in the results of these authors suggest that the brewing process conditions affected the composition of the residual BSG material. In fact, the conditions used for the brewing process were not reported in any of the studies presented in Table 2, and this is probably another factor with significant influence on the results.

Independently of the variations reported in the amount of each constituent in the BSG composition, this material is mainly composed of fibres (cellulose, hemicellulose and lignin) and protein (Table 2). Hemicellulose and cellulose are fractions constituted by sugars, among which xylose, arabinose and glucose are the most abundant in BSG. Sugars correspond to approximately half of the BSG composition on a dry weight basis, thus representing a very important fraction. Besides sugars, lignin (a polyphenolic macromolecule of complex structure) and proteins are also present in significant amounts in BSG. Essential amino acids represent approximately $30 \%$ of the total protein content, with lysine being the most abundant (14.3\%), followed by leucine $(6.12 \%)$, phenylalanine $(4.64 \%)$, isoleucine $(3.31 \%)$, threonine $(0.71 \%)$ and tryptophan $(0.14 \%)$. The non-essential amino acids in BSG (corresponding to $70 \%$ of the total protein content) include mainly histidine $(26.27 \%)$ and glutaminc acid $(16.59 \%)$, with minor amounts of aspartic acid (4.81\%), valine (4.61\%), arginine $(4.51 \%)$, alanine $(4.12 \%)$, serine $(3.77 \%)$, tyrosine $(2.57 \%)$, glycine $(1.74 \%)$, asparagine $(1.47 \%), \gamma$-aminobutyric acid $(0.26 \%)$ and glutamine $(0.07 \%) .^{12}$

Finally, BSG also contains a variety of minerals elements, among which silicon, phosphorus and calcium are the most abundant (Table 2). Silicon is also the most abundant mineral element in other cereals such as rice, oat and wheat straw, but the content of phosphorus and calcium in BSG is particularly higher than those commonly reported for these cereals.
Compared with other agro-industrial by-products (Table 3), ${ }^{13-18}$ BSG presents lower cellulose content but similar lignin content, which would allow its use as raw material for the production of valuable compounds such as activated charcoal, phenolic compounds, dispersant, emulsificant and chelant agents, pesticides, fertilizers, polymers, adhesives, components for resins, etc. ${ }^{19}$ On the other hand, BSG presents elevated hemicellulose content, which is higher than that present in several other crop by-products, including rice straw, wheat straw, rice husks, barley straw and oat straw. Protein in BSG is also present at elevated levels, while in other crop by-products it is usually found in minor proportions. The presence of hemicellulose sugars and protein in high amounts in BSG makes this material very interesting for food and biotechnological applications, as will be discussed in the next sections.

\section{TECHNOLOGIES FOR BSG USE}

As mentioned above, BSG is rich in sugars and proteins. Therefore the main and quickest alternative that has been used for its elimination is as animal feed. In the past, most of the BSG generated by brewing activities was disposed of to the environment. Currently, breweries usually supply this material at low cost to local farmers for use as cattle feed. However, BSG is a raw material of interest for application in different areas because of its low price, large availability throughout the year and valuable chemical composition. The following sections summarize and discuss the most recent efforts that have been made towards BSG use in food, in energy production and in chemical and biotechnological processes.

\section{BSG USE IN FEED AND FOOD, AND BENEFITS TO HEALTH}

The possibility of BSG application in the food area, both as animal feed and in the human diet, has been evaluated for a long time, and, increasingly, health benefits arising from the ingestion of BSG compounds have been found. As a consequence, many research centres continue investigating the possibility of using BSG in the manufacture of different food products. More recently, investigations have also been performed aimed at recovering compounds of interest from this material, which could be added to food products to promote differential characteristics and possible beneficial effects on health.

\section{Use as animal feed}

The main current application of BSG is as cattle feed, where it can be utilized directly in wet form (as separated from the mash tun) or as dry material. The high contents of fibre and protein in BSG together with the low cost of this by-product make it a substrate of great interest for use as animal feed. When combined with inexpensive nitrogen sources such as urea, for example, BSG is able to provide all the essential amino acids needed for animal nutrition. ${ }^{20}$ Additionally, the inclusion of BSG in the cow's diet increases milk production and the content of total solids while decreasing the content of fat in the milk produced. ${ }^{21,22}$

The important advantages resulting from the inclusion of BSG in cattle feed encouraged the application of this material in the feeding of other animals such as poultry, ${ }^{23-25}$ pigs $^{26,27}$ and fish. ${ }^{28-31}$ Again, positive effects such as body weight gain were reported as a consequence of BSG supplementation of the diet 
Table 2. Chemical composition of brewer's spent grain (BSG)

\begin{tabular}{|c|c|c|c|c|c|c|}
\hline Item & Mussatto and Roberto ${ }^{7}$ & Kanauchi et al. ${ }^{8}$ & Carvalheiro et al. ${ }^{9}$ & Silva et al. ${ }^{10}$ & Meneses et al. ${ }^{11}$ & Waters et al. ${ }^{12}$ \\
\hline \multicolumn{7}{|c|}{ Components ( $\mathrm{kg}^{-1}$ dry weight basis) } \\
\hline Cellulose (glucan) & 168 & 254 & 219 & 253 & 217 & 260 \\
\hline Hemicellulose & 284 & 218 & 296 & 419 & 192 & 222 \\
\hline Xylan & 199 & NR & 206 & NR & 136 & NR \\
\hline Arabinan & 85 & NR & 90 & NR & 56 & NR \\
\hline Lignin & 278 & 119 & 217 & 169 & 194 & NR \\
\hline Acetyl groups & 14 & NR & 11 & NR & NR & NR \\
\hline Proteins & 153 & 240 & 246 & NR & 247 & 221 \\
\hline Ashes & 46 & 24 & 12 & 46 & 42 & 11 \\
\hline Extractives & 58 & NR & NR & 95 & 107 & NR \\
\hline \multicolumn{7}{|c|}{ Minerals (mg kg ${ }^{-1}$ dry weight basis) } \\
\hline Silicon & 10740 & NR & NR & NR & NR & 1400 \\
\hline Phosphorus & 5186 & NR & NR & NR & 6000 & 4600 \\
\hline Calcium & 3515 & NR & NR & NR & 3600 & 2200 \\
\hline Magnesium & 1958 & NR & NR & NR & 1900 & 2400 \\
\hline Sulfur & 1980 & NR & NR & NR & 2900 & NR \\
\hline Potassium & 258.1 & NR & NR & NR & 600 & 700 \\
\hline Sodium & 309.3 & NR & NR & NR & 137.1 & 100 \\
\hline Iron & 193.4 & NR & NR & NR & 154.9 & 100 \\
\hline Zinc & 178.0 & NR & NR & NR & 82.1 & 100 \\
\hline Aluminium & 36.0 & NR & NR & NR & 81.2 & NR \\
\hline Manganese & 51.4 & NR & NR & NR & 40.9 & NR \\
\hline Cobalt & NR & NR & NR & NR & 17.8 & NR \\
\hline Copper & 18.0 & NR & NR & NR & 11.4 & NR \\
\hline Strontium & 12.7 & NR & NR & NR & 10.4 & NR \\
\hline lodine & NR & NR & NR & NR & 11.0 & NR \\
\hline Barium & 13.6 & NR & NR & NR & 8.6 & NR \\
\hline Chromium & 5.9 & NR & NR & NR & $<0.5$ & NR \\
\hline Molybdenum & NR & NR & NR & NR & 1.4 & NR \\
\hline Boron & NR & NR & NR & NR & 3.2 & NR \\
\hline
\end{tabular}

Table 3. Chemical composition of different agricultural by-products

Agricultural by-products

\begin{tabular}{|c|c|c|c|c|c|c|c|c|c|c|}
\hline \multirow{2}{*}{$\begin{array}{l}\text { Component } \\
\left(\mathrm{g} \mathrm{kg}^{-1}\right. \\
\text { dry weight basis) }\end{array}$} & \multicolumn{10}{|c|}{ Agricultural by-products } \\
\hline & $\begin{array}{c}\text { Rice } \\
\text { straw }^{13}\end{array}$ & $\begin{array}{l}\text { Wheat } \\
\text { straw }^{14}\end{array}$ & $\begin{array}{c}\text { Barley } \\
\text { straw }^{15}\end{array}$ & $\begin{array}{c}\text { Oat } \\
\text { straw }^{15}\end{array}$ & $\begin{array}{c}\text { Rice } \\
\text { husks }^{16}\end{array}$ & $\begin{array}{c}\text { Barley } \\
\text { husks }^{16}\end{array}$ & $\begin{array}{l}\text { Corn } \\
\text { cobs }^{16}\end{array}$ & $\begin{array}{c}\text { Corn } \\
\text { stover }^{14}\end{array}$ & $\begin{array}{l}\text { Sugarcane } \\
\text { bagasse }^{17}\end{array}$ & $\begin{array}{c}\text { Spent } \\
\text { coffee }^{18}\end{array}$ \\
\hline Cellulose & 434 & 450 & 401 & 398 & 367 & 214 & 344 & 407 & 431 & 86 \\
\hline Hemicellulose & 229 & 161 & 222 & 234 & 173 & 325 & 343 & 266 & 252 & 367 \\
\hline Lignin & 172 & 241 & 194 & 182 & 213 & 192 & 188 & 260 & 229 & NR \\
\hline Acetyl groups & NR & NR & 17 & 18 & 16 & 17 & 31 & NR & NR & 22 \\
\hline Proteins & NR & NR & 34 & 25 & 25 & 59 & 43 & NR & NR & 136 \\
\hline Ashes & 114 & 68 & 35 & 39 & 143 & 155 & 13 & 43 & 28 & 16 \\
\hline Extractives & NR & 80 & NR & NR & 88 & 14 & 5 & 23 & 43 & NR \\
\hline
\end{tabular}

of these animals. ${ }^{28}$ Nowadays, BSG is considered as a low-cost alternative to the feed ingredients used in poultry diets. However, most of the cell wall polysaccharides, including arabinoxylan and $\beta$-glucan, present in BSG are not digested in the gastrointestinal tracts of these birds, because they do not have the enzymes needed for hydrolysis of the polymer chains. ${ }^{32}$ Therefore xylanase and $\beta$-glucanase enzymes have been commonly added to BSG to overcome this problem.

\section{Incorporation in human diet}

Apart from being a material of interest for animal feed, BSG has also been considered as an ingredient of value for use in the 
human diet. In fact, the high content of fibre, protein and minerals present in BSG is very attractive to improve the nutritional value of foods. Additionally, the ingestion of BSG provides several health benefits, such as accelerated transit time, increased faecal weight and fat excretion (alleviating both constipation and diarrhoea), decreased gallstone incidence and reduced plasma cholesterol and postprandial serum glucose levels. ${ }^{33,34}$ These beneficial effects are attributed to the presence of glutamine-rich protein, noncellulosic polysaccharides and soluble dietary fibres, including $(1 \rightarrow 3,1 \rightarrow 4)$ - $\beta$-glucan, in BSG. When ingested in the form of a protein-rich fibrous foodstuff, BSG is able to improve the clinical condition and endoscopic score of patients with mild to moderate ulcerative colitis, which is associated with an increase in stool butyrate concentration. 8,35

Owing to all the above-mentioned benefits, the possibility of BSG application in food products has been extensively evaluated. There are many studies reporting, for example, the incorporation of BSG in the manufacture of bakery products such as breads, biscuits, cookies, muffins, cakes, waffles, pancakes, tortillas, snacks, doughnuts and brownies. To be incorporated in these products, BSG is firstly converted to flour, because its original form is too granular for direct application. ${ }^{36-39}$ The incorporation of BSG in bakery products increases the contents of protein, fibre and amino acids while decreasing the calorie content of the final product. ${ }^{12,20,36,40}$ Additionally, BSG incorporation in foods imparts higher water absorption and lower fat absorption capacities to the final product. However, some care must be taken when incorporating BSG in human food. Since BSG has a brownish colour, it is only recommended for application in coloured products such as some breads, cookies, cakes, etc. in order not to affect the final colour of the product. Moreover, the incorporation of only small amounts (up to $100 \mathrm{~g} \mathrm{~kg}^{-1}$ ) in food formulations has been recommended, with the objective of avoiding alterations in the flavour and texture of the final product. ${ }^{36-38,40,41}$

Although BSG has been mainly used to prepare bakery products, the use of this material to produce other food products has also been evaluated recently. One example is the use of BSG for the production of frankfurters, where the addition of BSG allowed the fibre content in these products to be increased without negatively affecting their sensory parameters. Since BSG promotes these characteristics in the final product, it was suggested for use as a fat substitute for producing high-fibre and low-fat meat products. ${ }^{42}$ Another recent application of BSG is for the production of tarhana, a fermented wheat flour/yoghurt product. The utilization of milled BSG in tarhana production resulted in acceptable soup properties in terms of most of the sensory properties. The slightly lower values of some sensory properties (colour, odour and taste) were considered to be compensated by the health benefits provided by the increased content of fibre in the product. ${ }^{43}$

Although the incorporation of BSG in food products contributes important properties, further research is still needed to improve the quality (appearance, texture and taste) of the final product as well as to evaluate consumer acceptance.

\section{Source of ingredients for food applications}

In recent years, bioactive compounds, including phenolic compounds, have received much attention for incorporation in food products owing to their potential to promote human health, such as antioxidant, antiallergenic, anti-inflammatory and antimicrobial effects and reduction of the incidence of diabetes and cancer as well as of the risk factors of cardiovascular diseases. ${ }^{44}$
Owing to these important beneficial effects on human health, research aimed at finding natural resources rich in bioactive phenolic compounds has intensified.

BSG is rich in bioactive phenolic compounds with antioxidant activity, which can be recovered by various extraction methods, including solid-liquid extraction, microwave-assisted extraction, enzymatic reactions and alkaline reactions. Among these methods, solid-liquid extraction using $60 \%(\mathrm{v} / \mathrm{v}$ ) acetone as solvent for 30 min at $60{ }^{\circ} \mathrm{C}$ proved to be highly efficient to extract antioxidant phenolic compounds from BSG. ${ }^{11}$ Ferulic and $p$-coumaric acids are the phenolic acids present in higher amounts in BSG and may contribute significantly to the antioxidant potential of this material. Flavonoids have also been suggested to be strongly correlated with the antioxidant capacity of BSG. ${ }^{11}$

Antioxidant phenolic compounds extracted from BSG represent a promising alternative for application in the food industry in order to avoid the use of synthetic antioxidants. This would be an interesting alternative for application of BSG, since antioxidant phenolic compounds are commercially expensive and have many industrial applications not only in food but also in the pharmaceutical area.

\section{BSG USE IN ENERGY PRODUCTION}

Several alternatives have been proposed for BSG use in energy production, including thermochemical conversion (pyrolysis, combustion), biogas production and ethanol production. The production of energy from BSG is motivated by the energy crisis that the world is currently experiencing. Additionally, the large availability of this material together with its chemical composition and low cost makes BSG a raw material of great interest for application in this area.

\section{Thermochemical conversion}

One of the possible alternatives to generate energy from biomass materials like BSG is by using thermochemical conversion technologies such as pyrolysis and combustion. BSG presents important net and gross calorific values of 18.64 and 20.14 MJ $\mathrm{kg}^{-1}$ dry mass respectively ${ }^{45}$ and therefore can be considered as an interesting raw material to produce energy by combustion. To be used in combustion processes, BSG must be initially dried to moisture content lower than $550 \mathrm{~g} \mathrm{~kg}^{-1}$, which can be done by pressure, for example. ${ }^{46}$ The heat generated by combustion of the BSG could be used to support the energetic demand of breweries in a brewery-integrated system. However, BSG combustion generates the emission of particles ${ }^{47}$ and toxic gases that contain nitrogen and sulfur dioxide at 1000-3000 and $480 \mathrm{mg} \mathrm{m}^{-3}$ respectively. ${ }^{48}$ For these reasons, it is very important to take special care when performing the combustion of BSG in order to avoid or minimize these problems.

Another interesting alternative is using BSG to produce charcoal bricks. The production process consists of an initial step where BSG is dried, followed by pressing and carbonization in a low-oxygen atmosphere. ${ }^{49}$ The charcoal bricks produced by this method have high calorific value $\left(27 \mathrm{MJ} \mathrm{kg}^{-1}\right)$, which is higher than the calorific value of the original BSG and similar to the calorific value of charcoals produced from other raw materials such as wood, sugarcane, grape bagasse, olive bagasse and hazelnut shell. ${ }^{50-52}$ On the other hand, charcoal bricks produced from BSG present burning properties inferior to those reported for sawdust charcoal, for example, because the ignition temperature is higher and the burning period is longer. ${ }^{53}$ 
Intermediate pyrolysis of BSG at $450{ }^{\circ} \mathrm{C}$ using a twin coaxial screw reactor known as a Pyroformer gives $29 \%$ yields of char, $51 \%$ of bio-oil and $19 \%$ of permanent gases. Bio-oil, which is the most abundant fraction obtained by this process, contains a complex mixture of low- to intermediate-molecular-weight hydrocarbons, including benzene, cyclooctatetraene, hexene, toluene, xylene, phenolic-derived aromatic compounds, undecanoic acid and methyl esters. ${ }^{54}$

\section{Biogas production}

Several studies have reported the possibility of producing biogas from BSG. This application can be considered especially suitable for obtaining thermal energy in breweries with few adverse environmental effects. Biogas contains approximately $55-65 \%$ methane, $30-45 \%$ carbon dioxide, traces of hydrogen sulfide and fractions of water vapour. Biogas production processes by anaerobic fermentation can be divided into two steps: (1) an initial hydrolytic step to promote complete degradation of the material; (2) a methanogenic step in which acidogenic microorganisms convert the macromolecules released from the previous hydrolytic stage to volatile fatty acids, acetate, butyrate and propionate, and subsequently methanogenic bacteria convert these volatile acids to methane. ${ }^{55}$ The hydrolysis step can be performed by using different methodologies such as chemical/thermal treatment, crushing (by wet rotor grinding or ball milling) or enzymatic treatment. The most important factor is to use conditions able to promote complete degradation of the material structure so that the next stage of conversion can be performed with elevated yields.

Anaerobic batch fermentation of BSG resulted in the production of biogas with a total yield of $3476 \mathrm{~cm}^{3}$ per $100 \mathrm{~g} \mathrm{BSG}$ after 15 days of digestion. ${ }^{55}$ The theoretical potential of methane production per tonne of BSG is estimated at $98 \mathrm{~N} \mathrm{~m}^{3}$ of methane. ${ }^{56}$ However, the biogas production from BSG is inhibited by intermediate lignocellulosic biodegradation products, mainly $p$-cresol. ${ }^{57}$ The inhibition is not prevented even by submitting BSG to mechanical, thermochemical or chemical pre-treatments. The biogas production from BSG is therefore a research area that merits great attention in order to develop a stable production process. The adaptation of anaerobic microbial biomass to elevated concentrations of $p$-cresol as well as submitting BSG to a biological pre-treatment stage with fungi or bacteria could be possible alternatives to overcome this problem. Currently, biogas production from BSG is limited to larger breweries owing to the economic constraints of smaller units.

\section{Ethanol production}

In the last decade, ethanol has experienced unseen levels of attention owing to its value as a fuel alternative to gasoline, the increase in oil prices, and climatic changes, as well as being a renewable and sustainable energy source that is efficient and safe to the environment. Currently, worldwide ethanol production is at high levels, and corn is the main raw material used for this purpose. However, as this kind of feedstock is essentially food, this scenario is expected to change owing to the incentive that has been given for the production of second-generation ethanol, i.e. ethanol produced from lignocellulosic waste materials. ${ }^{58}$ Various lignocellulosic raw materials have been studied for this purpose, among which BSG has also been considered owing to its high content of hemicellulose and cellulose fractions. In the last decade, interest in establishing a competitive process for second-generation ethanol production led to an intensification of research in this area, and BSG was considered as a promising raw material for this application, being evaluated in different kinds of processes using different microbial strains.

Both the hemicellulose and cellulose fractions of BSG can be used for ethanol production. In a recent study, ethanol was produced with $86.3 \%$ conversion efficiency by fermentation of the xylose-rich hemicellulosic hydrolysate produced by dilute acid hydrolysis of BSG with Pichia stipitis. This result was obtained without supplementing the BSG hydrolysate with nutrients, ${ }^{59,60}$ which is an important aspect for the economy of the process and makes BSG different from other raw materials used for second-generation ethanol production, such as sugarcane bagasse, which require the addition of nutrients to the fermentation medium for the efficient conversion of sugars to ethanol. ${ }^{61,62}$

In order to produce ethanol from cellulose, some pre-treatment of the raw material is required to make the extraction of glucose from cellulose easier, for subsequent use as a carbon source for fermentation. Pre-treatment may involve, for example, acid treatment, microwave digestion, ultrasonication or enzymatic hydrolysis, among others. Some recent literature data ${ }^{63-66}$ concerning ethanol production from BSG cellulose using different pre-treatment and fermentation conditions are presented in Table 4. The ethanol yield varied significantly according to the process utilized. For example, the hydrolysate prepared by enzymatic digestion of BSG pre-treated with $0.16 \mathrm{~mol} \mathrm{~L}^{-1}$ $\mathrm{HNO}_{3}$ was fermented to ethanol by $P$. stipitis NCYC 1540 and Kluyveromyces marxianus NCYC 1425, resulting in ethanol conversion yields of 63 and $45 \%$ of the maximum theoretical value respectively. ${ }^{63}$ An ethanol yield of $74 \mathrm{~g} \mathrm{~kg}^{-1}$ dry BSG was obtained by fermentation with Neurospora crassa DSM 1129 under aeration of 0.1 vvm using alkali-pre-treated BSG as raw material. ${ }^{64}$ This result was improved to $109 \mathrm{~g} \mathrm{~kg}^{-1}$ dry BSG (corresponding to $60 \%$ of the theoretical yield) when the fermentation was carried out under similar process conditions but using the fungus Fusarium oxysporum F3 ${ }^{65}$ (Table 4). Such results demonstrate that BSG has great potential for use in ethanol production, but establishment of the best fermentation conditions is fundamental to maximize the conversion results.

An alternative system that has been evaluated in order to improve the production of ethanol from BSG is a consolidated bioconversion process using the mesophilic fungus $F$. oxysporum F3. Using this system, the cellulolytic and hemicellulolytic enzymes are produced under solid state cultivation, while the alkalipre-treated BSG is converted to ethanol by $F$. oxysporum in a consecutive submerged fermentation. A yield of $65 \mathrm{~g} \mathrm{~kg}^{-1}$ dry BSG was obtained using alkali-pre-treated BSG under microaerobic conditions $(0.1 \mathrm{vvm})$, which corresponded to $30 \%$ of the theoretical ethanol yield based on the total glucose and xylose composition of $\mathrm{BSG}^{66}$ (Table 4).

Recently, a method for the production of fuel ethanol from BSG was patented. The method consists of the following steps: (1) pre-treatment of the BSG with acid and heat to degrade the hemicellulosic fraction; (2) hydrolysis of the pre-treated BSG with enzyme to convert starch and cellulosic material to simple sugars; (3) fermentation of the simple sugars to ethanol with an ethanol-producing microbe (which can be Zymomonas mobilis, Saccharomyces cerevisiae, Escherichia coli, Bacillus subtilis or Pichia pastoris); (4) distillation of the ethanol produced by fermentation; (5) dehydratation of the ethanol to remove water. ${ }^{67}$ 


\section{BSG USE IN CHEMICAL PROCESSES}

BSG is a raw material of interest for chemical processes either to obtain (by extraction) or produce (by chemical reaction) compounds of industrial interest. Several possible applications have been proposed for BSG use in this area, among which its use as an adsorbent material for wastewater treatment appears to be one of the most promising applications.

\section{Extraction of valuable compounds by chemical processes}

As mentioned above, BSG is rich in cellulose and hemicellulose polysaccharides, which are added value compounds with many industrial applications. In order to extract these compounds from the BSG structure, several chemical processes can be employed, among which acid and hydrothermal hydrolysis have been widely used. By chemical hydrolysis, cellulose can be converted into glucose, while hemicellulose can be converted into xylose and arabinose, which are the most abundant sugars present in this fraction of BSG. ${ }^{7} 11$

Depending on the conditions used for hydrolysis, the polysaccharide structure may not be completely hydrolysed and low-molecular-weight oligosaccharides are then obtained in the final reaction medium. The molecular weight of the oligosaccharides released from the BSG structure varies according to the temperature and reaction time used during the pretreatment. For example, a hydrolysate containing a variety of arabino-oligoxylosides with different structural features can be obtained by hydrothermal treatment of BSG at $150{ }^{\circ} \mathrm{C}$ for 60 and $120 \mathrm{~min} .{ }^{68}$ On the other hand, dilute acid hydrolysis of BSG at $120{ }^{\circ} \mathrm{C}$ using a liquid/solid ratio of $8 \mathrm{~g} \mathrm{~g}^{-1}, 100 \mathrm{mg}$ $\mathrm{H}_{2} \mathrm{SO}_{4} \mathrm{~g}^{-1}$ BSG and a reaction time of $17 \mathrm{~min}$ promotes the hydrolysis of the hemicellulose structure to the corresponding monomeric sugars with $92.7 \%$ efficiency. ${ }^{69}$ Heating by microwave radiation at $160{ }^{\circ} \mathrm{C}$ in the presence of $0.1 \mathrm{~mol} \mathrm{~L}^{-1} \mathrm{HCl}$ is also an efficient method to hydrolyse BSG polysaccharides, providing an $80 \%$ yield. $^{70}$

Alkaline hydrolysis using $\mathrm{NaOH}$ solution is efficient to extract lignin from BSG. ${ }^{71}$ The BSG lignin solubilized in the alkaline liquor can be separated by precipitation with $\mathrm{H}_{2} \mathrm{SO}_{4}{ }^{19}$ and used as starting material for a series of useful products such as dispersant, emulsificant and chelant agents, activated charcoal, polymers, adhesives and fertilizers, among others.

Hydroxycinnamic acids can also be recovered from the BSG structure by means of chemical treatment. Ferulic and $p$-coumaric acids are the most abundant hydroxycinnamic acids in BSG and can be efficiently recovered by alkaline hydrolysis using $20 \mathrm{~g} \mathrm{~L}^{-1}$ $\mathrm{NaOH}$ solution in a solid/liquid ratio of $1 \mathrm{~g}$ per $20 \mathrm{~g}$ at $120^{\circ} \mathrm{C}$ for 90 min. $^{72}$ Microwave-assisted extraction is also a technology with potential to extract polyphenols, including ferulic acid, from BSG. ${ }^{73}$ Considering that ferulic and $p$-coumaric acids have antioxidant properties and important industrial applications, the extraction of these acids from BSG offers new possibilities for the reuse of this industrial by-product in food, cosmetic and/or pharmaceutical areas.

Antioxidant phenolic compounds can also be recovered from BSG by extraction with solvents. Various solvents, including methanol, ethanol, acetone, hexane, ethyl acetate, water and mixtures of methanol/water, ethanol/water and acetone/water, can be used for this purpose. Nevertheless, acetone/water mixtures, especially at $60 \%(\mathrm{v} / \mathrm{v})$, are more efficient to release these compounds from the BSG structure. ${ }^{11}$ Antioxidant phenolic compounds extracted from BSG could be used as a natural and inexpensive alternative to synthetic antioxidants. 


\section{Raw material for pulp and paper production}

Owing to its fibrous nature, BSG is considered as a suitable raw material for use in the production of papers. BSG has already been used to prepare paper towels, business cards and coasters, conferring high-grade texture on these products. ${ }^{74}$ A more recent study reported the production of bleached cellulose pulp from BSG. A cellulose-rich pulp $\left(904 \mathrm{~g} \mathrm{~kg}^{-1}\right.$ ) with low hemicellulose and extractive contents (79 and $34 \mathrm{~g} \mathrm{~kg}^{-1}$ respectively) was obtained by soda pulping of acid-pre-treated BSG. Subsequently, the pulp was bleached by a totally chlorine-free sequence carried out in three stages, using $5 \%(\mathrm{v} / \mathrm{v})$ hydrogen peroxide in the first two stages and $0.25 \mathrm{~mol} \mathrm{~L}^{-1} \mathrm{NaOH}$ solution in the last stage. Using this procedure, a bleached pulp presenting a kappa number of 11.21, viscosity of $3.12 \mathrm{cP}$, brightness of $71.3 \%$, cellulose content of 957 $\mathrm{g} \mathrm{kg}^{-1}$ and residual lignin of $34 \mathrm{~g} \mathrm{~kg}^{-1}$ was obtained from BSG. ${ }^{75}$

\section{Adsorbent material}

One of the most interesting and promising applications of BSG in chemical processes is as an adsorbent for removing either organic compounds from waste gases or dyes from wastewater. The adsorption capacity of volatile organic compounds on pyrolysed BSG is similar to that on coconut shell charcoal. ${ }^{76}$

In aqueous solution, BSG is able to adsorb cadmium, lead and chromium with sorption capacities of $17.3,35.5$ and $18.94 \mathrm{mg}$ $\mathrm{g}^{-1}$ respectively. ${ }^{77,78}$ However, previous treatment of the BSG with $\mathrm{NaOH}$ is needed to enhance its metal sorption capacity. The capacity of BSG to adsorb cadmium, lead and chromium from aqueous solution is similar to the capacity reported for other materials such as tree fern, wheat bran, sugarcane bagasse, sugar beet pulp and coconut shell. ${ }^{79-82}$ However, a novel adsorbent consisting of esterified BSG was recently demonstrated as having improved ability to remove cadmium from aqueous solution. Esterified BSG presented very high efficiency for cadmium removal in a wide $\mathrm{pH}$ range of $4-8$, with a maximum adsorption capacity of $473.93 \mathrm{mg} \mathrm{g}^{-1}$, and showed good reusability during nine cycles of sorption/desorption. ${ }^{83}$

Another important and potential application of BSG as an adsorbent is for the removal of dye from wastewater. BSG presents elevated capacity to adsorb acid orange 7 dye (AO7), which is commonly used in the paper and textile industries and whose presence in effluents causes serious environmental problems. BSG is able to adsorb this dye with an adsorption capacity of

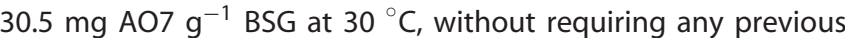
treatment to improve the adsorption. ${ }^{10,84}$ This result opens up real possibilities for BSG application in this area, since adsorption processes must be efficient, fast and use cheap adsorbents to compete with other techniques.

BSG can also be used as a raw material to produce activated carbons, which are widely used for the purification of water and gases, among many other applications. The process to produce activated carbon from BSG lignin consists of the following steps: recovery of the lignin from the BSG structure by alkaline treatment, followed by its precipitation with $\mathrm{H}_{2} \mathrm{SO}_{4}$ and the impregnation/activation of the recovered lignin with $3 \mathrm{~g} \mathrm{H}_{3} \mathrm{PO}_{4}$ $\mathrm{g}^{-1}$ lignin at $600{ }^{\circ} \mathrm{C}$. The activated carbon produced from BSG presents an adsorption capacity similar to or even better than that of some commercial products and shows potential for use on wastewater treatment, since it is able to absorb phenolic compounds and metallic ions (mainly $\mathrm{Ni}, \mathrm{Fe}, \mathrm{Cr}$ and $\mathrm{Si}$ ) from liquid media. ${ }^{85}$

\section{BSG USE IN BIOTECHNOLOGICAL PROCESSES}

BSG is a substrate of high potential for use in biotechnological processes, since it is rich in polysaccharides, proteins and minerals. Therefore many studies have been focused on the use of BSG as a raw material to extract or to produce valuable compounds by fermentation or enzymatic processes. The most recent advances on the use of BSG in biotechnological processes are discussed below.

\section{Substrate for microorganism cultivation/enzyme production}

The main evidence that BSG is a good substrate for cultivation of microorganisms lies in the fact that, as separated from the lauter tun, it is a very unstable material able to deteriorate rapidly via microbial activity. Such rapid deterioration occurs mainly as a consequence of the elevated content of water that it possesses when separated from the lauter tun $\left(800 \mathrm{~g} \mathrm{~kg}^{-1}\right)$ and the presence of proteins and sugars in its composition. Up to eight different fungal strains from the genera Aspergillus, Fusarium, Mucor, Penicillium and Rhizopus were found in BSG when it was stored in wet form in gunnysacks for 30 days. ${ }^{86}$ Therefore it is strongly recommended to reduce the moisture content of BSG to less than $100 \mathrm{~g} \mathrm{~kg}^{-1}$ in order to safely store it.

Taking this important property of BSG into account, several studies have been proposed using this material as a low-cost substrate for cultivation of fungal strains. Species of Aspergillus, Pleurotus, Lentinus, Trametes, Neurospora and Agrocybe, for example, are able to grow successfully when cultivated in BSG. However, not only the elevated moisture content and the presence of proteins and sugars favour the fungal growth in BSG, but some physical properties of this material such as particle size, volume weight, specific density, porosity and water-holding capacity also influence the growth of these microorganisms. ${ }^{87}$ Besides fungi, Streptomyces bacteria are also able to grow and show enhanced sporulation when cultivated in a protein fraction isolated from BSG. ${ }^{88}$

In many cases the production of enzymes by cultivation of microorganisms in BSG has been reported. Some examples include the production of $\alpha$-amylase by cultivation of Aspergillus oryzae $^{89-92}$ B. subtilis, ${ }^{93}$ Bacillus licheniformis ${ }^{94}$ and Bacillus sp. KR-8104; ${ }^{95}$ cellulases by Trichoderma reesei ${ }^{96}$ and $N$. crassa; ${ }^{64}$ xylanases by Streptomyces avermitilis, ${ }^{97}$ Aspergillus awamori, ${ }^{98}$ N. crassa ${ }^{64}$ Aspergillus fumigatus, ${ }^{99}$ Talaromyces stipitatus and Humicola grisea; ${ }^{100}$ feruloyl esterase by S. avermitilis, ${ }^{97} \mathrm{~N}$. crassa, ${ }^{64}$ T. stipitatus and $H$. grisea; $i^{100}$ laccases by Trametes versicolor; ${ }^{101}$ and arabino-furanosidases and acetyl esterase by N. crassa. ${ }^{64}$ In most cases it is not necessary to supplement the BSG with any nutritional source to obtain efficient enzyme production, but in some cases the addition of nutrients such as sources of nitrogen, amino acids, vitamins and/or inorganic compounds may improve the enzyme yield.

\section{Extraction of valuable compounds by enzymatic processes}

As mentioned above, some chemical methods can be used to extract valuable compounds from the BSG structure. However, some biological methods may also be used for this purpose, with the additional advantage that they do not generate toxic effluents, therefore being considered more environmentally friendly. In this sense, several enzymes have been used to extract valuable compounds from BSG. Mixtures of polysaccharide hydrolases from Aspergillus japonicus, A. versicolor and T. reesei, for example, are able to hydrolyse more than $42 \%$ of the total polysaccharides in BSG to sugars in only 1 day. ${ }^{102}$ Some commercial microbial 
proteases are also able to release the non-cellulosic glucose, a portion of feruloylated arabinoxylan and over $50 \%$ of the protein from BSG after $24 \mathrm{~h}$ of hydrolysis. ${ }^{103}$ Nevertheless, it is known that lignocellulosic materials such as BSG present a rigid structure that makes the action of enzymes difficult. Additionally, the presence of lignin in these materials decreases the efficiency of enzymatic hydrolysis. The negative effect of lignin on the enzymatic hydrolysis of BSG has been reported recently. ${ }^{104}$

Taking this into account, an alternative to obtain elevated yields of soluble sugars after enzymatic hydrolysis of BSG is to pre-treat this material (with dilute acid or base, for example) so as to make the polysaccharide structure more accessible to the enzymes. In order to avoid extra costs for the process, the pre-treatment stage should be planned in a biorefinery concept, where the liquid fraction obtained from the pre-treatment stage is also utilized for a valuable application. For example, Mussatto et al. ${ }^{104}$ pre-treated BSG by sequential processes of dilute acid hydrolysis and alkaline hydrolysis in order to extract glucose by enzymatic hydrolysis of the cellulose fraction, attaining a conversion yield of cellulose to glucose of $85.6 \%$. This value was further improved to $93.1 \%$ when the conditions of agitation, enzyme loading and substrate concentration used for enzymatic hydrolysis were optimized. ${ }^{105}$ The liquid fraction obtained from the acid pre-treatment of BSG was used for the production of xylitol, ${ }^{69,106-108}$ while the liquid fraction obtained from the alkaline pre-treatment was used for the production of activated carbon. ${ }^{85}$

Besides extracting sugars, enzymes can also be used to extract other compounds from the BSG structure, such as hydroxycinnamic acids (ferulic and $p$-coumaric acids). A combination of esterase from Aspergillus niger and xylanase from Trichoderma viride was able to extract $30 \%$ of the total ferulic acid present in BSG. ${ }^{109}$ An enzyme preparation from the thermophilic fungus Humicola insolens released almost all the ferulic acid and 9\% of the $p$-coumaric acid present in BSG. ${ }^{110}$

\section{Raw material for fermentation processes}

Several alternatives have been proposed to use BSG as a raw material for the production of value-added compounds by fermentation. The possibility of using BSG as a carbon and/or nutrient source has been demonstrated in both solid state and submerged fermentation systems for the production of a variety of compounds of industrial interest.

As mentioned above, the sugar-rich hydrolysate produced by dilute acid hydrolysis of BSG can be used for ethanol production by fermentation using different microorganisms. BSG hydrolysate can also be successfully used for the production of xylitol by yeasts such as Candida guilliermondii ${ }^{69,106-108}$ and Debaryomyces hansenii. ${ }^{111,112}$ Optimization of the conditions for dilute acid hydrolysis of BSG is fundamental to produce a hydrolysate rich in xylose but with low amounts of inhibitory compounds (furfural, hydroxymethylfurfural, acetic acid and phenolic compounds). By optimizing the hydrolysis conditions, xylitol was produced by C. guilliermondii with good yield $\left(0.70 \mathrm{~g} \mathrm{~g}^{-1}\right)$ and productivity (0.45 $\left.\mathrm{g} \mathrm{L}^{-1} \mathrm{~h}^{-1}\right){ }^{69}$ Based on experimental results, the xylitol production from BSG is estimated as approximately $0.107 \mathrm{~g} \mathrm{~g}^{-1}$ raw material. ${ }^{106}$ However, the xylitol yield and productivity can be improved by increasing the xylose content available for conversion into xylitol. ${ }^{107,108}$ Xylitol can be produced by C. guilliermondii from concentrated BSG hydrolysate ( $70 \mathrm{~g} \mathrm{~L}^{-1}$ xylose) with a yield of 0.78 $\mathrm{g} \mathrm{g}^{-1}$ and productivity of $0.58 \mathrm{~g} \mathrm{~L}^{-1} \mathrm{~h}^{-1}$. An important advantage of this process compared with the processes using hydrolysates produced from other raw materials is that BSG hydrolysate does not require supplementation with nutrients to be efficiently used as a fermentation medium for xylitol production. ${ }^{108}$

Debaryomyceshansenii has the ability to simultaneously produce xylitol and arabitol when cultivated in a pentose (xylose and arabinose)-rich hydrolysate obtained by autohydrolysis followed by $\mathrm{H}_{2} \mathrm{SO}_{4}$ hydrolysis of BSG. ${ }^{111,112}$ This is a very interesting fact, because BSG has a significant amount of arabinose sugar in its composition, and this pentose sugar is not easily assimilated by many microorganisms. Conversion of arabinose to value-added products such as arabitol contributes to complete utilization of BSG.

BSG can also be used in fermentation processes for the production of lactic acid. The fermentation of a molasses/BSG/coconut water medium by Lactobacillus plantarum resulted in highly efficient $(93-95 \%)$ production of lactic acid after 4 days of processing. ${ }^{113}$ In more recent studies, lactic acid was produced by Lactobacillus delbrueckii from a glucose-rich medium obtained by enzymatic hydrolysis of BSG cellulose with a commercial cellulase preparation. ${ }^{114,115}$ The best bioconversion performance occurred when the hydrolysate was supplemented with nutrients and the $\mathrm{pH}$ was controlled at 6 . Under these conditions, lactic acid was produced with a yield and productivity of $0.99 \mathrm{~g} \mathrm{~g}^{-1}$ glucose and $0.59 \mathrm{~g} \mathrm{~L}^{-1} \mathrm{~h}^{-1}$ respectively. The nutritionally enriched BSG hydrolysate was considered as an efficient substrate for lactic acid production by L. delbrueckii. ${ }^{115}$

An interesting and novel application that has been reported for BSG is as raw material for the production of a distilled beverage. ${ }^{59}$ In order to produce this distillate, BSG is initially submitted to a hydrothermal process that aims to extract aroma compounds, and the produced extract is submitted to fermentation and distillation processes. The produced distillate contains 38 volatile compounds contributing to the aroma and flavour and presents organoleptic quality acceptable for human consumption.

Finally, the possibility of using BSG as an additive for fermentation processes has also been reported. The addition of a neutralised acid extract of BSG to the wort enhanced the yeast performance during the fermentation for beer production, and the produced beer presented similar quality to that fermented without BSG addition. ${ }^{116}$

\section{Carrier for cell immobilization}

Fermentation systems using immobilized cells are being increasingly utilized owing to the several advantages that they present compared with traditional fermentation systems using free cells. Such systems are eco-friendly and the immobilized cells completely maintain their biological functions with increased stability, leading to increased cell productivity. As a consequence of the high cell concentration in the fermentation medium, the efficiency and productivity of the process are also improved. In addition, immobilized cell systems make the separation of the cells from the fermented broth easier for subsequent use in repeated batch operations. ${ }^{117,118}$ Nevertheless, the use of a suitable immobilization carrier is fundamental to obtain an effective system for each particular application.

A variety of inorganic and organic materials can be used as supports for cell immobilization; however, those of natural origin are commonly preferred, since they are renewable, biodegradable, non-toxic, inexpensive and readily available. In this sense, several studies have evaluated the possibility of using BSG as a carrier for cell immobilization. BSG can be successfully used for 
immobilization of S. cerevisiae in order to produce beer by a highgravity continuous process. ${ }^{119,120}$ It is also a promising biocatalyst for use in batch winemaking at low fermentation temperatures. ${ }^{121}$ Additionally, BSG is a good material for use as a cell immobilization carrier for the production of pectinase by $K$. marxianus CCT $3172^{122}$ and for the production of fructooligosaccharides and $\beta$-fructofuranosidase by $A$. japonicus. ${ }^{118}$ As a whole, BSG can be considered as a material with great potential for use for cell immobilisation, since it has an irregular structure and a nonhomogeneous chemical composition, which provide active sites that are easily colonised by microorganisms. Although BSG can be used as an immobilization carrier without any previous processing, treatment of this material with acid and/or base solutions may be useful to improve its immobilization capacity.

\section{ECONOMIC AND ENVIRONMENTAL ASPECTS RELATED TO BSG USE}

Many possibilities for BSG valorization have been reported, but none of them has been implemented on an industrial scale up till now. Currently, supplying this wet material to local farmers for use as cattle feed continues to be the main solution of the breweries for its elimination, since this is a cheap alternative that avoids the energy spend needed for drying the BSG. However, the costs of transporting BSG are significant, corresponding to an average of U\$16 per tonne of wet BSG transported a distance of 5 miles ( $\sim 8 \mathrm{~km})$. Therefore BSG is usually supplied to local farmers (preferentially no further than 5 miles from the brewery) in order to minimize the costs involved in its elimination. Nevertheless, in some cases, the BSG produced may surpasses the demand for cattle feed required by the nearby farmers. In other cases, there are no farms close to the breweries. Both situations result in increased amounts of BSG, with nowhere to send it. The most common option that has been used in these cases is disposal to the environment. However, more recently, some breweries have surpassed this problem by using BSG as an energy source for their own companies. By installing special combustion equipment for the purpose of burning BSG to produce steam energy, the breweries are able to recover over $50 \%$ of their energy costs. Using spent grain as a source of fuel allows breweries to conserve energy and also benefit the environment, as it reduces leftover grain waste (100000 t of BSG leaves only $2000 t$ or less of ash as a result of the process) and eliminates the need to transport BSG to nearby farmers, with consequent reduction of carbon emissions.

Although the burning of BSG for energy generation can be an interesting and fast solution for the breweries to eliminate this by-product, other promising alternatives for BSG reuse have been proposed, as discussed above. Some of them could be of interest for the brewing industry directly, such as using BSG for the production of fuel ethanol for transportation, for the production of paper for the labels of their packaging, as a nutrient source for yeast cultivation and as a carrier for cell immobilization. In most of these cases, successful implementation of such technologies in breweries would be expected owing to their technical nature (equipment, facilities, laboratories and so on). However, BSG can also be a raw material of interest for other industries, as discussed above. Independently of the application that will be given to the BSG (in the brewery or in other industries), a technological and economic analysis would be useful in order to verify the possibility of implementation of the proposed technologies on an industrial scale. In this sense, a recent study was carried out in order to draw recommendations on the technological, economic and environmental feasibility for implementation of a biorefinery for BSG utilization as raw material for the production of xylitol, lactic acid, activated carbon and phenolic acids, taking into account the Brazilian case. Full mass integration of water plus full energy integration was the configuration with the best economic and environmental performance, proportioning an economic margin of $62.25 \%$, with a potential environmental impact of 0.012 potential environmental impact (PEI) $\mathrm{kg}^{-1}$ products, and the carbon footprint of the processing stage representing $0.96 \mathrm{~kg}$ $\mathrm{CO}_{2}$-equivalent emission (e) $\mathrm{kg}^{-1} \mathrm{BSG}^{123}$

\section{CONCLUSIONS}

BSG is an important agro-industrial by-product in terms of quantity generated and valuable chemical composition. Studies have been focused for decades on the reuse of this material for valuable applications, but in the last decade the research in this area has been intensified, possibly motivated by environmental and economic concerns. The current literature suggests a number of possible applications for e BSG reuse in food, energy, chemical and biotechnological processes. Important advantages and benefits resulting from these applications have been demonstrated. The advances that have been observed in this research area suggest that the implementation of industrial processes for BSG reuse may be a close reality.

\section{REFERENCES}

1 Mussatto SI, Dragone G and Roberto IC, Brewer's spent grain: generation, characteristics and potential applications. J Cereal Sci 43:1 - 14 (2006).

2 Mussatto SI, Biotechnological potential of brewing industry byproducts, in Biotechnology for Agro-industrial Residues Utilisation, Vol. 1, ed. by Nigam PS and Pandey A. Springer, Dordrecht, pp. 313-326 (2009).

3 USDA, World Agricultural Production Archives. United States Department of Agriculture, Washington, DC (2012).

4 Zhang $Y$, Ghaly AE and Li B, Availability and physical properties of residues from major agricultural crops for energy conversion through thermochemical processes. Am J Agric Biol Sci 7:312-321 (2012).

5 De Mori C and Minella $E$, Aspectos econômicos e conjunturais da cultura da cevada. Embrapa Trigo Documentos Online 139 [Online]. (2012). Available: http://www.cnpt.embrapa. br/biblio/do/p_do139.htm [10 September 2013].

6 Kim $S$ and Dale $B E$, Global potential bioethanol production from wasted crops and crop residues. Biomass Bioenergy 26:361-375 (2004).

7 Mussatto SI and Roberto IC, Chemical characterization and liberation of pentose sugars from brewer's spent grain. J Chem Technol Biotechnol 81:268-274 (2006).

8 Kanauchi O, Mitsuyama K and Araki Y, Development of a functional germinated barley foodstuff from brewer's spent grain for the treatment of ulcerative colitis. J Am Soc Brew Chem 59:59-62 (2001).

9 Carvalheiro F, Esteves MP, Parajó JC, Pereira H and Gírio FM, Production of oligosaccharides by autohydrolysis of brewery's spent grain. Bioresour Technol 91:93-100 (2004).

10 Silva JP, Sousa S, Rodrigues J, Antunes H, Porter JJ, Goncalves I, et al., Adsorption of acid orange 7 dye in aqueous solutions by spent brewery grains. Separ Purif Technol 40:309-315 (2004).

11 Meneses NGT, Martins S, Teixeira JA and Mussatto SI, Influence of extraction solvents on the recovery of antioxidant phenolic compounds from brewer's spent grains. Separ Purif Technol 108:152-158 (2013)

12 Waters DM, Jacob F, Titze J, Arendt EK and Zannini E, Fibre, protein and mineral fortification of wheat bread through milled and fermented brewer's spent grain enrichment. Eur Food Res Technol 235:767-778 (2012) 
13 Roberto IC, Mussatto SI and Rodrigues RCLB, Dilute-acid hydrolysis for optimization of xylose recovery from rice straw in a semi-pilot reactor. Ind Crops Prod 17:171 - 176 (2003).

14 Tröger N, Richter D and Stahl R, Effect of feedstock composition on product yields and energy recovery rates of fast pyrolysis products from different straw types. J Anal Appl Pyrol 100:158-165 (2013).

15 Pronyk C and Mazza G, Fractionation of triticale, wheat, barley, oats, canola, and mustard straws for the production of carbohydrates and lignins. Bioresour Technol 106:117-124 (2012).

16 Parajó JC, Garrote G, Cruz JM and Dominguez H, Production of xylooligosaccharides by autohydrolysis of lignocellulosic materials. Trends Food Sci Technol 15:115-120 (2004).

17 Rocha GJM, Gonçalves AR, Oliveira BR, Olivares EG and Rossell CEV, Steam explosion pretreatment reproduction and alkaline delignification reactions performed on a pilot scale with sugarcane bagasse for bioethanol production. Ind Crops Prod 35:274-279 (2012).

18 Mussatto SI, Carneiro LM, Silva JPA, Roberto IC and Teixeira JA, A study on chemical constituents and sugars extraction from spent coffee grounds. Carbohydr Polym 83:368-374 (2011).

19 Mussatto SI, Fernandes M and Roberto IC, Lignin recovery from brewer's spent grain black liquor. Carbohydr Polym 70:218-223 (2007).

20 Huige NJ, Brewery by-products and effluents, in Handbook of Brewing, ed. by Hardwick WA. Marcel Dekker, New York, NY, pp. 501-550 (1994).

21 Belibasakis NG and Tsirgogianni D, Effects of wet brewers grains on milk yield, milk composition and blood components of dairy cows in hot weather. Anim Feed Sci Technol 57:175-181 (1996).

22 Sawadogo L, Sepehri $\mathrm{H}$ and Houdebine LM, Presence of a factor stimulating prolactin and growth hormone secretion in brewers' spent grains. Reprod Nutr Dev 29:139-146 (1989).

23 Gondwe TNP, Mtimuni JP and Safalaoh ACL, Evaluation of brewery by-products replacing vitamin premix in broiler finisher diets. Indian J Anim Sci 69:347-349 (1999).

24 McIntosh GH, Newman RK and Newman CW, Barley foods and their influence on cholesterol metabolism. World Rev Nutr Diet 77:89-108 (1995).

25 Oh JCS, Chng AL, Jesudason RB and Sim TS, Incorporation of microbiologically treated spent brewery grains into broiler rations. Lett Appl Microbiol 13:150-153 (1991).

26 Dung NNX, Manh LH and Uden P, Tropical fibre sources for pigs - digestibility, digesta retention and estimation of fibre digestibility in vitro. Anim Feed Sci Technol 102:109-124 (2002).

27 Yaakugh IDI, Tegbe TSB, Olorunju SAS and Aduku AO, Replacement value of brewer's dried grain for maize on performance of pigs. $J$ Sci Food Agric 66:465-471 (1994).

28 Kaur VI and Saxena PK, Incorporation of brewery waste in supplementary feed and its impact on growth in some carps. Bioresour Technol 91:101-104 (2004).

29 Muzinic LA, Thompson KR, Morris A, Webster CD, Rouse DB and Manomaitis L, Partial and total replacement of fish meal with soybean meal and brewer's grains with yeast in practical diets for Australian red claw crayfish Cherax quadricarinatus. Aquaculture 230:359-376 (2004).

30 Shimeno S, Mima T, Kinoshita $\mathrm{H}$ and Kishi S, Inclusion of malt protein flour to diet for fingerling yellowtail. Nippon Suisan Gakkaishi 60:521-525 (1994)

31 Yamamoto T, Marcouli PA, Unuma T and Akiyama T, Utilization of malt protein flour in fingerling rainbow-trout diets. Fish Sci 60:455-460 (1994)

32 Denstadli V, Westereng B, Biniyam HG, Ballance S, Knutsen SH and Svihus B, Effects of structure and xylanase treatment of brewer's spent grain on performance and nutrient availability in broiler chickens. Br Poultry Sci 51:419-426 (2010).

33 Fastnaught CE, Barley fiber, in Handbook of Dietary Fiber, ed. by Cho S, Dreher ML and Cho SS. Marcel Dekker, New York, NY, pp. 519-542 (2001).

34 Brennan CS and Cleary LJ, The potential use of $(1 \rightarrow 3,1 \rightarrow 4)-\beta$ D-glucans as functional food ingredients. J Cereal Sci 42:1-13 (2005).

35 Bamba T, Kanauchi O, Andoh A and Fujiyama Y, A new prebiotic from germinated barley for nutraceutical treatment of ulcerative colitis. J Gastroenterol Hepatol 17:818-824 (2002).

36 Hassona $\mathrm{HZ}$, High fibre bread containing brewer's spent grains and its effect on lipid metabolism in rats. Nahrung 37:576-582 (1993).
37 Miranda MZ, Grossmann MVE and Nabeshima EH, Utilization of brewer's spent grain for the production of snacks with fiber. 1 . Physicochemical characteristics. BrazArch Biol Technol 37:483-493 (1994).

38 Miranda MZ, Grossmann MVE, Prudencio Ferreira SH and Nabeshima $\mathrm{EH}$, Utilization of brewer spent grain (BSG) for production of snacks with fiber. 2. Sensory analysis of snacks. Braz Arch Biol Technol 37:9-21 (1994).

39 Öztürk S, Özboy Ö, Cavidoglu I and Köksel H, Effects of brewer's spent grain on the quality and dietary fibre content of cookies. J Inst Brew 108:23-27 (2002)

40 Ktenioudaki A, Chaurin V, Reis SF and Gallagher E, Brewer's spent grain as a functional ingredient for breadsticks. Int J Food Sci Technol 47:1765-1771 (2012).

41 Townsley PM, Preparation of commercial products from brewer's waste grain and trub. Tech Q Master Brew Assoc Am 16:130-134 (1979).

42 Özvural EB, Vural H, Gökbulut I and Özboy-Özbas Ö, Utilization of brewer's spent grain in the production of Frankfurters. Int J Food Sci Technol 44:1093-1099 (2009).

43 Ozboy-Ozbas O, Hancer A and Gokbulut I, Utilization of sugarbeet fiber and brewers' spent grain in the production of tarhana. Zuckerindustrie 135:496-501 (2010).

44 Martins S, Mussatto SI, Martínez-Avila G, Montañez-Saenz J, Aguilar $\mathrm{CN}$ and Teixeira JA, Bioactive phenolic compounds: production and extraction by solid-state fermentation. A review. Biotechnol Adv 29:365-373 (2011).

45 Russ W, Mörtel H and Meyer-Pittroff R, Application of spent grains to increase porosity in bricks. Construct Build Mater 19:117-126 (2005).

46 Zanker $\mathrm{G}$ and Kepplinger WL, The utilization of spent grains in the brewery integrated system. Brauwelt 142:1742-1747 (2002).

47 Meyer-Pittroff R, Utilization of spent brewer's grain for energy production. Brauwelt 128:1156-1158 (1988).

48 Keller-Reinspach HW, Emissions during the combustion of spent brewer's grains. Brauwelt 129:2316-2319 (1989).

49 Okamoto H, Sato K, Yagi N, Inoue M, Yamasaki S, Ishida S, et al., Development of production process of charcoal bricks from spent grain. Kagaku Kogaku Ronbunshu 28:137-142 (2002).

50 Ffoulkes D, Elliot R and Preston TR, Feasibility of using pressed sugar cane stalk for the production of charcoal. Trop Anim Prod 5:125-129 (1980).

51 Encinar JM, Beltran FJ, Bernalte A, Biro A and Gonzales JF, Pyrolysis of two agricultural residues: olive and grape bagasse. Influence of particle size and temperature. Biomass Bioenergy 11:397-409 (1996).

52 Demirbas A, Properties of charcoal derived from hazelnut shell and the production of briquettes using pyrolytic oil. Energy 24:141-150 (1999).

53 Sato K, Yagi N, Okamoto H, Inoue M, Ajiri T and Shibata J, Physical property and burning property of spent grain charcoal. Shigen to Sozai 117:587-590 (2001).

54 Mahmood ASN, Brammer JG, Hornung A, Steele A and Poulston $\mathrm{S}$, The intermediate pyrolysis and catalytic steam reforming of brewers spent grain. J Anal Appl Pyrol 103:328-342 (2013). DOI: 10.1016/j.jaap.2012.09.009.

55 Ezeonu FC and Okaka ANC, Process kinetics and digestion efficiency of anaerobic batch fermentation of brewer's spent grains (BSG). Process Biochem 31:7-12 (1996).

56 Sežun M, Grilc V and Logar RM, Anaerobic digestion of mechanically and chemically pretreated lignocellulostic substrate. CISA, Environmental Sanitary Engineering Center, Third Int. Symp. onEnergy from Biomass and Waste, Venice (2010).

57 Sežun M, Grilc V, Zupancic GD and Logar RM, Anaerobic digestion of brewery spent grain in a semi-continuous bioreactor: inhibition by phenolic degradation products. Acta Chim Slov 58:158-166 (2011).

58 Mussatto SI, Dragone G, Guimarães PMR, Silva JPA, Carneiro LM, Roberto IC, et al., Technological trends, global market, and challenges of bio-ethanol production. Biotechnol Adv 28:817-830 (2010).

59 Meneses NGT, Produção de bebida destilada e etanol combustível a partir de resíduos da indústria cervejeira. MSc Thesis, Centre of Biological Engineering, University of Minho, Braga (2011).

60 Meneses NGT, Teixeira JA and Mussatto SI, Produção de etanol a partir de subproduto cervejeiro. Bol Biotecnol 3:27-28 (2013). 
61 Vargas Betancur GJ and Pereira Junior N, Sugar cane bagasse as feedstock for second generation ethanol production. Part II: Hemicellulose hydrolysate fermentability. Electron J Biotechnol 13(5) (2010). DOI: 10.2225/vol13-issue5-fulltext-8.

62 Ferreira AD, Mussatto SI, Cadete RM, Rosa CA and Silva SS, Ethanol production by a new pentose-fermenting yeast strain, Scheffersomyces stipitis UFMG-IMH 43.2, isolated from the Brazilian forest. Yeast 28:547-554 (2011).

63 White JS, Yohannan BK and Walker GM, Bioconversion of brewer's spent grains to bioethanol. FEMS Yeast Res 8:1175-1184 (2008).

64 Xiros C, Topakas E, Katapodis P and Christakopoulos P, Hydrolysis and fermentation of brewer's spent grain by Neurospora crassa. Bioresour Technol 99:5427-5435 (2008).

65 Xiros C and Christakopoulos P, Enhanced ethanol production from brewer's spent grain by a Fusarium oxysporum consolidated system. Biotechnol Biofuels 2:4 (2009). DOI: 10.1186/1754-6834-2-4

66 Xiros C, Topakas E, Katapodis P and Christakopoulos P, Evaluation of Fusarium oxysporum as an enzyme factory for the hydrolysis of brewer's spent grain with improved biodegradability for ethanol production. Ind Crops Prod 28:213-224 (2008).

67 Birkmire S, Duff B, Lindeman C, Spooner J and Yancey M, Converting spent brewers grain into ethanol includes hydrolyzing pretreated spent brewers grain with enzyme to convert starch and cellulosic material to simple sugars, and fermenting simple sugars into ethanol with ethanol-producing microbe. US Patent 2010196979A1 (2010).

68 Kabel MA, Carvalheiro F, Garrote G, Avgerinos E, Koukios E, Parajó JC, et al., Hydrothermally treated xylan rich by-products yield different classes of xylo-oligosaccharides. CarbohydrPolym 50:47-56 (2002).

69 Mussatto $\mathrm{SI}$ and Roberto IC, Acid hydrolysis and fermentation of brewer's spent grain to produce xylitol. I Sci Food Agric 85:2453-2460 (2005)

70 Macheiner D, Adamitsch BF, Karver F and Hampel WA, Pretreatment and hydrolysis of brewers' spent grains. Eng Life Sci 3:401-405 (2003).

71 Mussatto SI, Dragone G, Rocha GJM and Roberto IC, Optimum operating conditions for brewer's spent grain soda pulping. Carbohydr Polym 64:22-28 (2006).

72 Mussatto SI, Dragone G and Roberto IC, Ferulic and $p$-coumaric acids extraction by alkaline hydrolysis of brewer's spent grain. Ind Crops Prod 25:231-237 (2007)

73 Moreira MM, Morais S, Barros AA, Delerue-Matos C and Guido LF, A novel application of microwave-assisted extraction of polyphenols from brewer's spent grain with HPLC-DAD-MS analysis. Anal Bioanal Chem 403:1019-1029 (2012).

74 Ishiwaki N, Murayama H, Awayama H, Kanauchi $\mathrm{O}$ and Sato $\mathrm{T}$ Development of high value uses of spent grain by fractionation technology. Tech Q Master Brew Assoc Am 37:261 - 265 (2000).

75 Mussatto SI, Rocha GJM and Roberto IC, Hydrogen peroxide bleaching of cellulose pulps obtained from brewer's spent grain. Cellulose 15:641-649 (2008).

76 Chiang PC, Chang P and You JH, Innovative technology for controlling VOC emissions. J Hazard Mater 31:19-28 (1992).

77 Low KS, Lee CK and Liew SC, Sorption of cadmium and lead from aqueous solutions by spent grain. Process Biochem 36:59-64 (2000).

78 Low KS, Lee CK and Low CH, Sorption of chromium(VI) by spent grain under batch conditions. J Appl Polym Sci 82:2128-2134 (2001).

79 Ho YS and Wang CC, Pseudo-isotherms for the sorption of cadmium ion onto tree fern. Process Biochem 39:759-763 (2004).

80 Farajzadeh MA and Monji AB, Adsorption characteristics of wheat bran towards heavy metal cations. Separ PurifTechnol 38:197-207 (2004).

81 Sharma DC and Forster CF, A preliminary examination into the adsorption of hexavalent chromium using low-cost adsorbents. Bioresour Technol 47:257-264 (1994).

82 Sekar M, Sakthi V and Rengaraj S, Kinetics and equilibrium adsorption study of lead(II) onto activated carbon prepared from coconut shell. J Colloid Interface Sci 279:307-313 (2004).

83 Li Q, Chai L and Qin W, Cadmium(II) adsorption on esterified spent grain: equilibrium modeling and possible mechanisms. Chem Eng J 197:173-180 (2012).

84 Silva JP, Sousa S, Goncalves I, Porter JJ and Ferreira-Dias S, Modeling adsorption of acid orange 7 dye in aqueous solutions to spent brewery grains. Separ Purif Technol 40:163-170 (2004).
85 Mussatto SI, Fernandes M, Rocha GJM, Orfão JJM, Teixeira JA and Roberto IC, Production, characterization and application of activated carbon from brewer's spent grain lignin. Bioresour Technol 101:2450-2457 (2010).

86 Sodhi HS, Garcha HS and Kiran U, Screening of mycoflora of spent-up brewers' grains for aflatoxin production. J Res Punjab Agric Univ 22:331-336 (1985)

87 Wang D, Sakoda A and Suzuki M, Biological efficiency and nutritional value of Pleurotus ostreatus cultivated on spent beer grain. Bioresour Technol 78:293-300 (2001).

88 Szponar B, Pawlik KJ, Gamian A and Dey ES, Protein fraction of barley spent grain as a new simple medium for growth and sporulation of soil actinobacteria. Biotechnol Lett 25:1717-1721 (2003).

89 Francis F, Sabu A, Nampoothiri KM, Szakacs G and Pandey A, Synthesis of $\alpha$-amylase by Aspergillus oryzae in solid-state fermentation. $J$ Basic Microbiol 42:320-326 (2002).

90 Francis F, Sabu A, Nampoothiri KM, Ramachandran S, Ghosh S, Szakacs $\mathrm{G}$, et al., Use of response surface methodology for optimizing process parameters for the production of $\alpha$-amylase by Aspergillus oryzae. Biochem Eng J 15:107-115 (2003).

91 Bogar B, Szakacs G, Tengerdy RP, Linden JC and Pandey A, Production of $\alpha$-amylase with Aspergillus oryzae on spent brewing grain by solid substrate fermentation. Appl Biochem Biotechnol 102/103:453-461 (2002).

$92 \mathrm{Xu} \mathrm{H}$, Sun L, Zhao D, Zhang B, Shi Y and Wu Y, Production of $\alpha$-amylase by Aspergillus oryzae As 3951 in solid state fermentation using spent brewing grains as substrate. J Sci Food Agric 88:529-535 (2008).

93 Duvnjak Z, Budimir A and Suskovic J, Effect of spent grains from beer production on production of $\alpha$-amylase by Bacillus subtilis $21+$. Prehrambeno Tehnol Rev 21:97-101 (1983).

94 Okita H, Yamashita H and Yabuuchi S, Production of microbial enzymes using brewers' spent grain. Hakko Kogaku Kaishi 63:55-60 (1985).

95 Hashemi M, RazaviSH, Shojaosadati SA and Mousavi SM, The potential of brewer's spent grain to improve the production of $\alpha$-amylase by Bacillus sp. KR-8104 in submerged fermentation system. New Biotechnol 28:165-172 (2011).

96 Sim TS and Oh JCS, Spent brewery grains as substrate for the production of cellulases by Trichoderma reesei QM9414. J Ind Microbiol 5:153-158 (1990).

97 Bartolomé B, Gómez-Cordovés C, Sancho Al, Díez N, Ferreira P, Soliveri J, et al., Growth and release of hydroxycinnamic acids from brewer's spent grain by Streptomyces avermitilis CECT 3339. Enzyme Microb Technol 32:140-144 (2003).

98 Bhumibhamon O, Production of acid protease and carbohydrate degrading enzyme by Aspergillus awamori. Thai J Agric Sci 11:209-222 (1978)

99 Souza DT, Bispo ASR, Bon EPS, Coelho RRR and Nascimento RP, Production of thermophilic endo- $\beta$-1,4-xylanases by Aspergillus fumigatus FBSPE-05 using agro-industrial by-products. Appl Biochem Biotechnol 166:1575-1585 (2012).

100 Mandalari G, Bisignano G, Lo Curto RB, Waldron KW and Faulds CB, Production of feruloyl esterases and xylanases by Talaromyces stipitatus and Humicola grisea var. thermoidea on industrial food processing by-products. Bioresour Technol 99:5130-5133 (2008).

101 Dhillon GS, Kaur S and Brar SK, In-vitro decolorization of recalcitrant dyes through an eco-friendly approach using laccase from Trametes versicolor grown on brewer's spent grain. Int Biodeterior Biodegrad 72:67-75 (2012).

102 Khan AW, Lamb KA and Schneider $\mathrm{H}$, Recovery of fermentable sugars from the brewers' spent grains by the use of fungal enzymes. Process Biochem 23:172-175 (1988).

103 Faulds CB, Collins S, Robertson JA, Treimo J, Eijsink VGH, Hinz SWA, et al., Protease-induced solubilisation of carbohydrates from brewers' spent grain. J Cereal Sci 50:332-336 (2009).

104 Mussatto SI, Fernandes M, Milagres AMF and Roberto IC, Effect of hemicellulose and lignin on enzymatic hydrolysis of cellulose from brewer's spent grain. Enzyme Microb Technol 43:124-129 (2008).

105 Mussatto SI, Dragone G, Fernandes M, Milagres AMF and Roberto IC, The effect of agitation speed, enzyme loading and substrate concentration on enzymatic hydrolysis of cellulose from brewer's spent grain. Cellulose 15:711-721 (2008).

106 Mussatto SI, Dragone G and Roberto IC, Kinetic behavior of Candida guilliermondii yeast during xylitol production from brewer's spent grain hemicellulosic hydrolysate. Biotechnol Prog 21:1352-1356 (2005). 
107 Mussatto SI, Dragone G and Roberto IC, Influence of the toxic compounds present in brewer's spent grain hemicellulosic hydrolysate on xylose-to-xylitol bioconversion by Candida guilliermondii. Process Biochem 40:3801-3806 (2005).

108 Mussatto SI and Roberto IC, Establishment of the optimum initial xylose concentration and nutritional supplementation of brewer's spent grain hydrolysate for xylitol production by Candida guilliermondii. Process Biochem 43:540-546 (2008).

109 Bartolomé B, Faulds CB and Williamson G, Enzymic release of ferulic acid from barley spent grain. J Cereal Sci 25:285-288 (1997).

110 Faulds CB, Mandalari G, Locurto R, Bisignano G and Waldron KW, Arabinoxylan and mono- and dimeric ferulic acid release from brewer's grain and wheat bran by feruloyl esterases and glycosyl hydrolases from Humicola insolens. Appl Microbiol Biotechnol 64:644-650 (2004).

111 Carvalheiro F, Duarte LC, Lopes S, Parajó JC, Pereira H and Gírio FM, Evaluation of the detoxification of brewery's spent grain hydrolysate for xylitol production by Debaryomyces hansenii CCMI 941. Process Biochem 40:1215-1223 (2005).

112 Duarte LC, Carvalheiro F, Lopes S, Marques S, Parajo JC and Girio FM, Comparison of two posthydrolysis processes of brewery's spent grain autohydrolysis liquor to produce a pentose-containing culture medium. Appl Biochem Biotechnol 113/116:1041-1058 (2004).

113 Cabacang R, Joson L, Conoza E and Dela Cruz E, Lactic acid production from local agricultural resources. Biotechnol Sustain Util Biol Resour Trop 11:237-242 (1997).

114 Mussatto SI, Fernandes M, Dragone G, Mancilha IM and Roberto IC, Brewer's spent grain as raw material for lactic acid production by Lactobacillus delbrueckii. Biotechnol Lett 29:1973-1976 (2007).
115 Mussatto SI, Fernandes M, Mancilha IM and Roberto IC, Effects of medium supplementation and $\mathrm{pH}$ control on lactic acid production from brewer's spent grain. Biochem Eng J 40:437-444 (2008).

116 Kado H, Ishii S, Takoi K, Mitani Y and Shinotsuka K, Effects of spent grains or their extract on yeast performance. Tech Q Master Brew Assoc Am 36:187-190 (1999).

117 Santos JC, Mussatto SI, Dragone G, Converti A and Silva SS, Evaluation of porous glass and zeolite as cells carriers for xylitol production from sugarcane bagasse hydrolysate. Biochem Eng J 23:1 - 9 (2005).

118 Mussatto SI, Aguilar CN, Rodrigues LR and Teixeira JA, Fructooligosaccharides and $\beta$-fructofuranosidase production by Aspergillus japonicus immobilized on lignocellulosic materials. J Mol Catal B 59:76-81 (2009).

119 Dragone G, Mussatto SI and Almeida e Silva JB, High gravity brewing by continuous process using immobilised yeast: effect of wort original gravity on fermentation performance. J Inst Brew 113:391-398 (2007).

120 Dragone G, Mussatto SI and Almeida e Silva JB, Influence of temperature on continuous high gravity brewing with yeasts immobilized on spent grains. Eur Food Res Technol 228:257-264 (2008).

121 Athanasios M, Paul L, Argyro B, Athanasios K and Michael K, Ambient and low temperature winemaking by immobilized cells on brewer's spent grains: effect on volatile composition. Food Chem 104:918-927 (2007).

122 Almeida C, Brányik T, Moradas-Ferreira P and Teixeira J, Continuous production of pectinase by immobilized yeast cells on spent grains. J Biosci Bioeng 96:513-518 (2003).

123 Mussatto SI, Moncada J, Roberto IC and Cardona CA, Technoeconomic analysis for brewer's spent grains use on a biorefinery concept: the Brazilian case. Bioresour Technol 148:302-310 (2013). 